\title{
ペーパークラフト風車の開発と学生による 学生のための技術者教育の継続的な実践
}

Development of Paper Craft Wind Turbine and Continuous Practice of Engineering Education for the Student by the Student

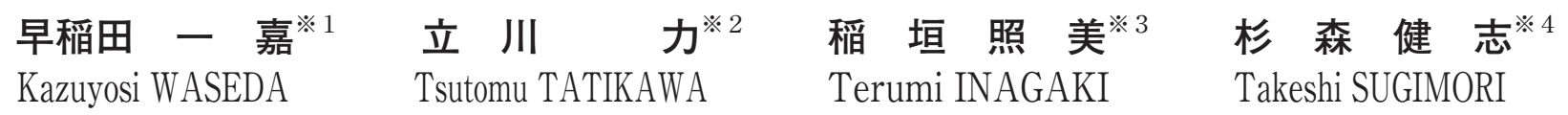

\begin{abstract}
This research planned and practiced "the engineer education for the student by the student with the aid of an inter-regional association". We used a newly developed paper craft modeled three dimensional upwind type wind turbines, and exhibited the paper craft for a series of regional science festivals. The paper craft is connected to a development of new science teaching materials throughout the appropriate evaluation.

Keywords: Science \& Engineering Education, Environmental Education, Creative Exercise, Community, Sustainable

キーワード : 理科学教育, 工学教育, 環境教育, ものづくり, 地域貢献, サスティナブル
\end{abstract}

\section{1.はじめに}

国民の科学技術に関する調查分析報告（2001年度文 部科学省科学技術対策研究所版 $)^{1)}$ では, 国民の「環 境問題」に対する関心の高さが示されている一方, 国 民の「科学技術」に対する関心の低さも指摘されてい る.ここでは, 我が国の理科離れが13歳以上になると 急激に進行し, 大人 (18歳以上69歳まで) の科学技術 知識に対する理解度が先進16力国中14位と極めて深刻 な状況にあることが指摘されている。 また，2004年度 文部科学省科学技術対策研究所版の科学技術指標 - 日 本の科学技術の体系的分析 $-{ }^{2)}$, 2008年度文部科学省 科学技術対策研究所版の科学技術システムの課題に関 する代表的研究・有識者の意識定点調査（科学技術シ ステム定点調查2007 ${ }^{3}$ P 2008 年度文部科学省科学技 術対策研究所版のインターネットを利用した科学技術 に関する意識調查の試み ${ }^{4)}$ でも，同様な趣旨が繰り 返し展開されている.

一方, OECDによる理数学リテラシーの平均得点に 関する国際比較 ${ }^{5)}$ では, 2000年の学力調查対象であ る32力国のうち日本は数学リテラシー 1 位・科学リテ ラシー 2 位, 2003 年の学力調查対象である 41 カ国のう ち日本は数学リテラシー 6 位・科学リテラシー 1 位と いう結果が報告されている，2006年度には，56力国の

平成 22 年 2 月 4 日受付

※ 1 神戸市立工業高等専門学校

$※ 2$ 茨城大学技術部

※ 3 茨城大学工学部

※ 茨城大学大学院理工学研究科機械工学専攻大学院生
うち日本は数学リテラシー 10 位・科学リテラシー 5 位に転落した。また, 国立教育政策研究所による追跡 調查 ${ }^{6)}$ によると,「理科は面白い」と考える生徒の割 合が学年進行とともに減少し, 高校生になると $50 \%$ に まで減少していることが憂慮されている.こうした理 科学を取巻く背景は, 科学技術立国である日本の将来 の「ものづくり」に対する深刻な問題に発展しかねな い.

一方, 「ものづくり」に対する考え方も, 経済優先 から環境優先に急速にシフトされつつある. 近年では, 環境省事務次官会見要旨 $(2009 \text { 年 } 6 \text { 月 } 25 \text { 日 })^{7)}$ にも見 られるように, グリーン・ニューディール，すなわち 環境配慮型の経済発展が打ち出され, 地域発展と自然 環境を強く意識した経済活動の必要性が叫ばれるよう になってきた.「ものづくり」立国である日本としては, 地域貢献と同時に, その担い手として将来を嘱望され る青少年への「ものづくり」教育を具現化させ, 環境 問題に配慮させつつ人間生活に役立つ「ものづくり」 の理念と感覚を身に付けさせて行かねばならないであ ろう.

したがって, 一連の研究では, 地域連携に基づいた 継続的な技術者教育の実践を通じた理工学系大学院生 のコミュニケーション及びプレゼンテーション能力の 向上と地域住民（小学校児童や中学校生徒など）への 理科学への啓蒙を意図した。すなわち, 茨城大学理 工学研究科の大学院生自らが, 大学と地域コミュニ ティー相互の連携組織を活用して問題解決能力とコ ミュニケーション及びプレゼンテーション能力の涵養 
を図るとともに, 学部学生向け専門基礎教育としての 機械工学実験教材の開発や地域青少年向け理科学教室 の開催を通じて環境問題や理科学への興味や関心の向 上を図った．大学院生自らが体験型イベント「ものづ くり体験理科教室」を企画・運営し, 学部学生や地域 の小・中学生に夢と現実の中継ぎをしながら「ものづ くり」への興味の喚起と理科離れの防止を目指してい る.この活動は, 茨城大学を知って貫う絶好の広報活 動にもなり得るであろう。具体的な研究目的は, 以下 の 4 つである．1）地域貢献を志向した地域に根ざし た理工学技術者の養成とコミュニケーション及びプレ ゼンテーション能力の涵養，2） サスティナブルな環 境教育の具現化による教育教材の開発，3）青少年の 理工学離れ防止, 4) 茨城大学の広報活動である。こ こで意図するサスティナブルな環境教育とは, 無尽蔵 かつクリーンなエネルギー形態の一つである風力エネ ルギーを利用した風車を物理的に正しくモデル化し， それによって環境問題への興味や関心の向上を図るこ とである

前報 ${ }^{8)}$ では, 単なる小中高生向きの理科教育教材 としてだけではない, 大学課程においても流体工学の 基礎を可視的に学べる教材として渦輪による渦運動に 着目し, 学生 (大学院生等) による学生 (学部生等) のための技術者教育の継続的な実践と評価について述 べた。ここでは, 過去数年に亘る学生自身による継続 的な技術改善と地域向け理科学教室の開催を通じてコ ミュニケーション及びプレゼンテーション能力の涵養 を図る努力を続けた。

一方, 本研究では, 流体工学の基礎的な現象を教材 として活用した前報に基づき, より応用的かつ環境教 育を志向したペーパークラフト風車を教材として新た に考案し, 地域連携を活用した学生による学生のため の技術者教育の継続的な実践を意図した。ここでは，

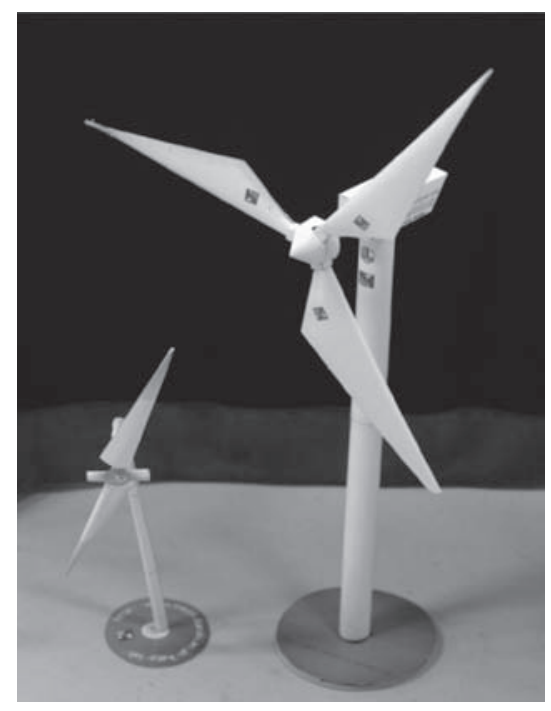

図 1 ペーパークラフト風車

(左：小型風車, 右：大型風車)
平成16年から本学工学部内に大学院生を中心とした風 力研究会 (会員数: 例年10名程度にて推移) を立ち上 げ，実機のモデル化からまず開始した。

\section{2. ペーパークラフト風車}

「風力発電」は自然エネルギーの一形態である風力 を活用しており, 地球温暖化や化学的な公害を排出し ない環境に優しいエネルギー資源である。そのため， 温暖化を始めとする地球環境問題や自然エネルギーに 関心を持たせ易い教材となる。ここでは, 風力発電に 供する水平軸アップウインド型風車を独自にモデル化 し, 図 1 ～図 5 に示したようなペーパークラフト風車 を開発した，本ペーパークラフトは，世界で初めて流 体力学的な考察に基づいて開発されたものであり, 小 型風車用（図 2 ），大型風車用（図 3 と図 4 ）の 2 種 類である。一般に, 実機と相似な形態をリアルにモデ ル化してしまうと, 翼形状も複雑になり, 組立ても難 しくなってしまう。しかしながら, 開発したペーパー クラフト風車では, 実機の翼形状を忠実にモデル化す ることに成功しつつ, 小学生でも取り扱いが可能なよ うに簡便な製作プロセスに最大限の配慮を払いなが ら，それらの相反する要件をバランス良く配合させて ある. すなわち, 従来から存在するペーパークラフト

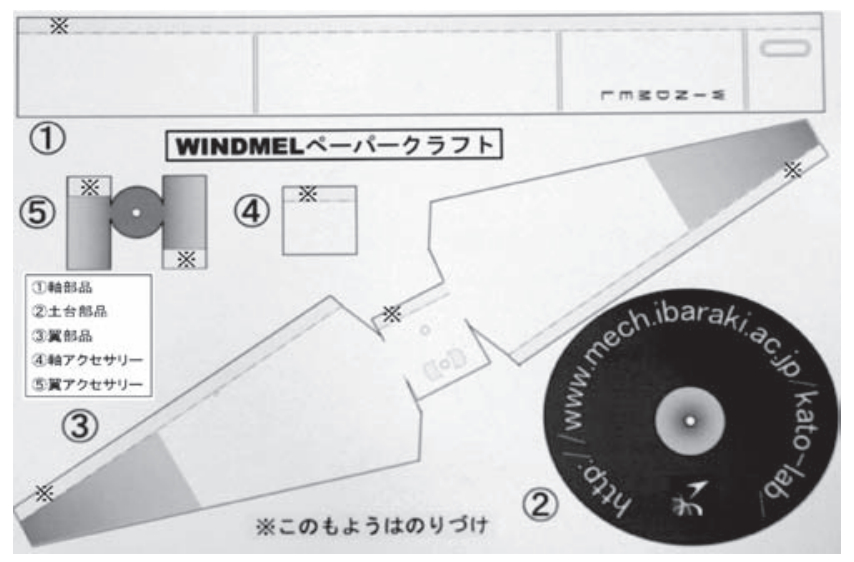

図 2 小型ペーパークラフト風車用台紙

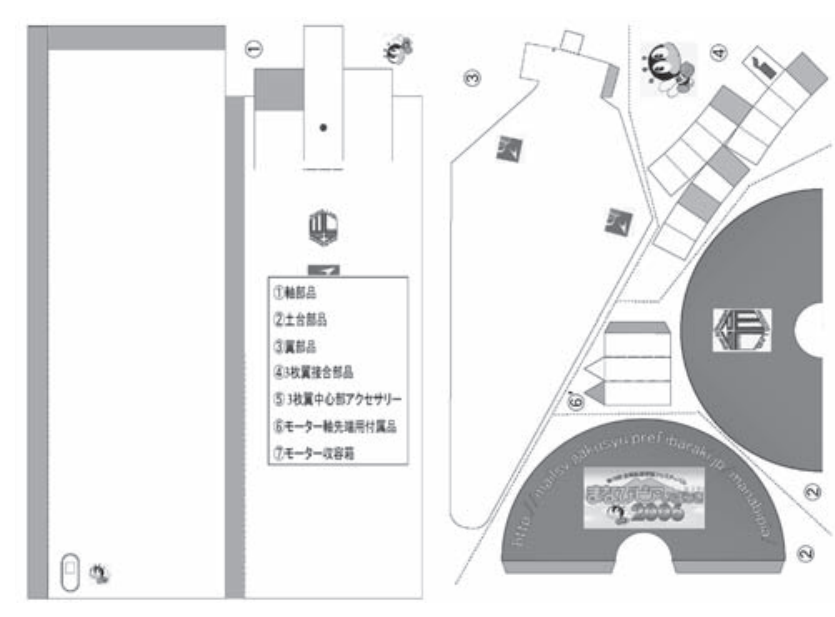

図 3 大型ペーパークラフト風車用台紙 1 


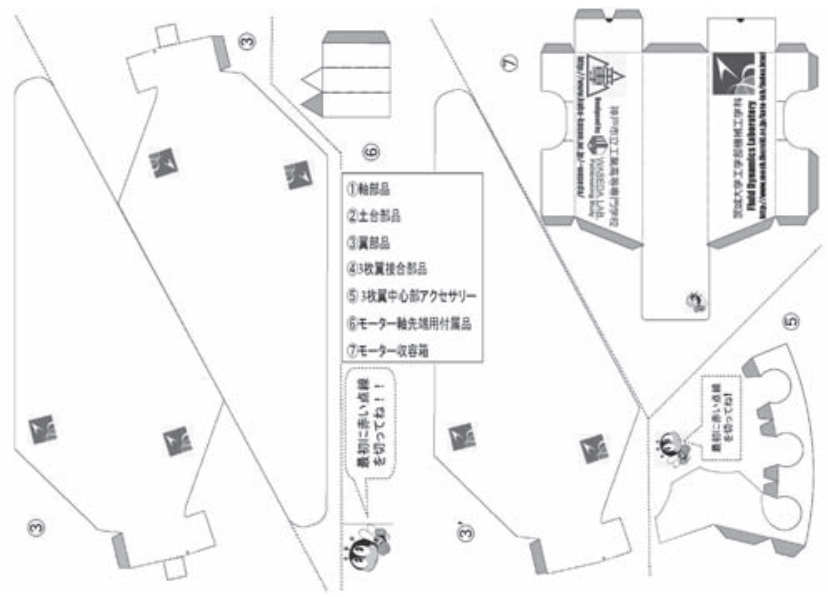

図 4 大型ペーパークラフト風車用台紙 2

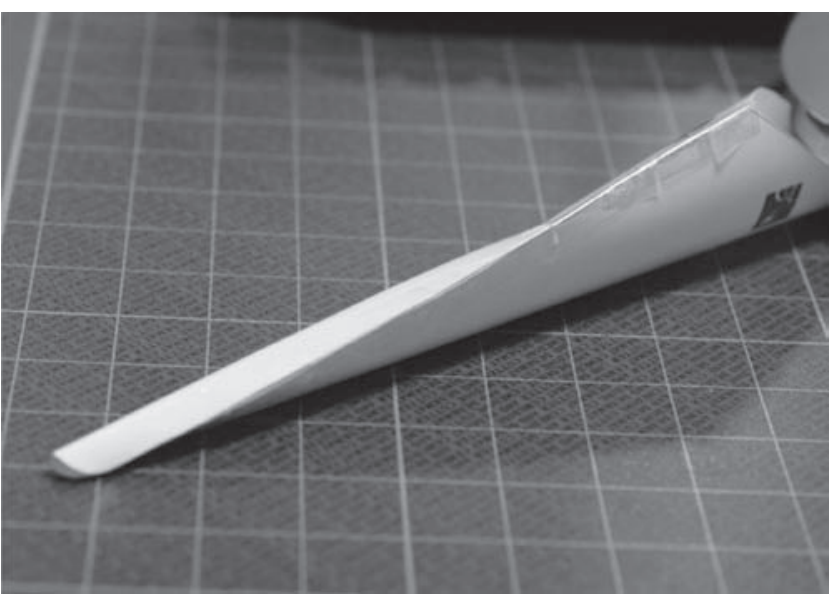

図 5 翼のひねり

風車では，翼形状が二次元的であるが故に実物感を創 出できない。一方，新たに開発したペーパークラフト 風車では, 翼部品(3)に対する貼り合わせ方の工夫と「ひ ねり」によって三次元な翼形状のモデル化を可能とし た（図 5 参照）。すなわち，以下に記述した幾つかの 工夫が本ペーパークラフト風車を三次元翼化する際の 独創的な特徵となる（図 6 参照）；1）同一長さ $\ell$ を 有した翼後縁接合部（糊付け部），2）テーパ角 $\theta_{1}$, $\theta_{2}\left(\theta_{1}<\theta_{2}\right)$ を有した翼後縁接合部 (糊付け部), 3 ) 翼背面長さ $Z_{1}$ と翼腹面長さ $Z_{2}$ の相違 $\left(Z_{1}<Z_{2}\right)$. さ らに，翼のアスペクト比を大きくして見せかけの翼厚 を増大させた。これらの工夫により，ペーパークラフ 卜完成後に実物感を伴う達成感や充実感が得られると ともに，ものづくりへの関心や興味を高められるもの と考えている.

大型ペーパークラフト風車では, 発電用モーターと 直結させてLEDを点灯させ，発電状況を視覚化する 仕組みも加えた。これまでも電子オルゴールや電力計 などを使用して発電状況を感知させていたが，視覚装 置であるLEDの導入により風力エネルギーと電気エ ネルギーの変換プロセスが一目瞭然となり, 風力発電 の仕組みを体験的に面白く学習させることが可能と

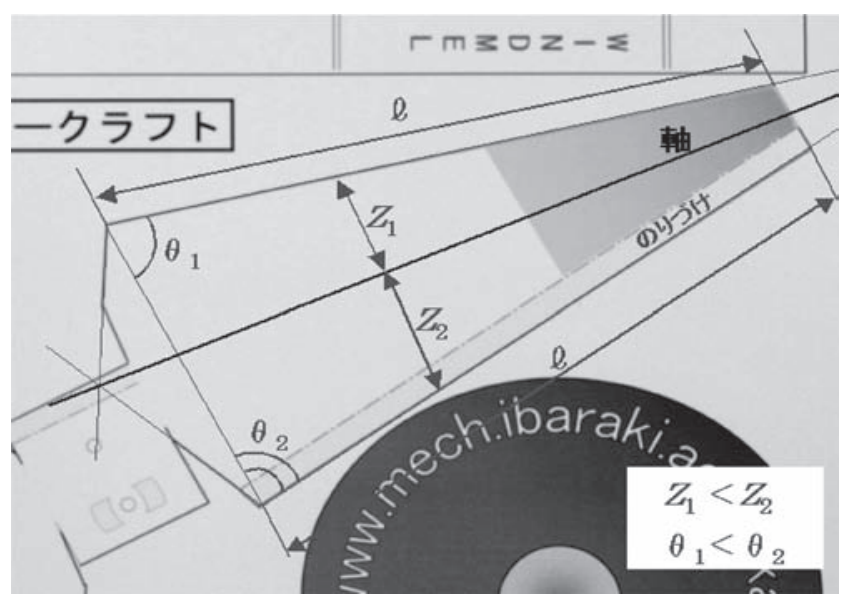

図 6 翼のひねりの仕組み

なった，すなわち，綺麗なイルミネーションの仕組み も付加することで, 大人から子供に至る参加者に興味 や関心を引き付けると同時に, 風車・風力発電に対し て好意的な印象を植え付けられるものと考えられる. 大型風車用のペーパークラフトは, 小型のそれに比べ て製作難易度がより高い複雑な構造となっており, 完 成時の達成感もより大きい.

\section{3. ものづくり体験理科教室への応用}

\section{1 ペーパークラフトの実践}

独自に開発したペーパークラフト風車は，地域貢献 を意図した継続的な環境教育の実践を通じた理工学系 大学院生のコミュニケーション及びプレゼンテーショ ン能力の向上と, 地域住民（小学校児童や中学校生徒 など）への理科学の啓蒙を意図している，著者等は, 茨城大学の周辺で毎年開催される茨城県日立市の「ひ たち環境都市フェス夕」と東海村の「とうかい環境フェ ス夕」に本ペーパークラフト風車を持ち込み, 本学大 学院生（茨城大学風力研究会員）によるものづくり理 科・環境教育講座をここ数年連続して展開している. ここでは，それらの成果について述べる，なお，毎年 茨城大学工学部で開催される工学祭へも, ペーパーク ラフト風車を活用した「ものつくり理科教室」を地域 住民向けに展開している.

図 7 ～図11は，平成21年 7 月 $18 ， 19$ 日に開催された ひたち環境都市フェスタにおける活況振りを示したも のである。フェス夕当日は, 本学大学院生による指導 の下，小学生を中心に老若男女様々な年齢層にペー パークラフト風車の製作をさせた，参加者には，まず 初めにペーパークラフトの工程を説明した後に作業を 開始させ，作業がやや困難な箇所においては参加者か ら適宜質問を受けながら必要に応じて大学院生と協 力し合った．参加者の多くには保護者が同伴してお り，親子で協力し合っている光景が目立った。フェス 夕には報道メディアや一般企業も参加しており, 大学 院生が保護者や企業の技術者など様々な参加者と展示 


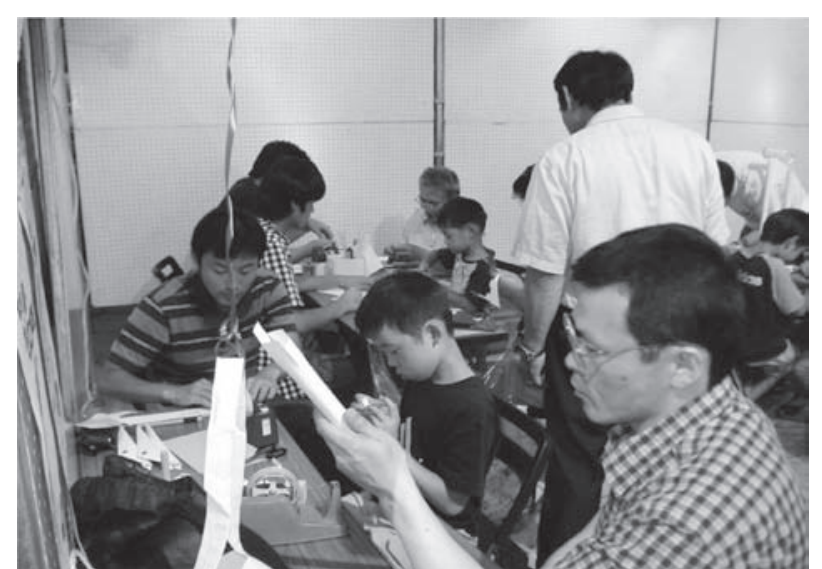

図 7 ひたち環境都市フェスタの様子

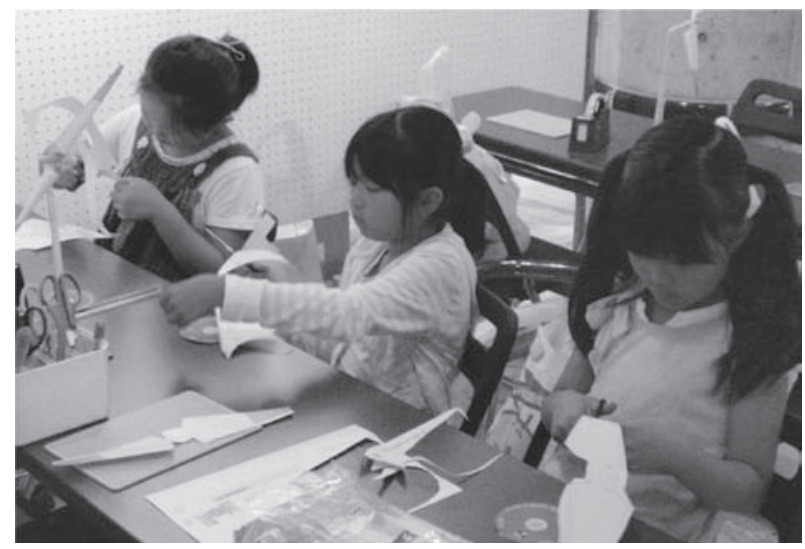

図 8 ひたち環境都市フェスタの様子

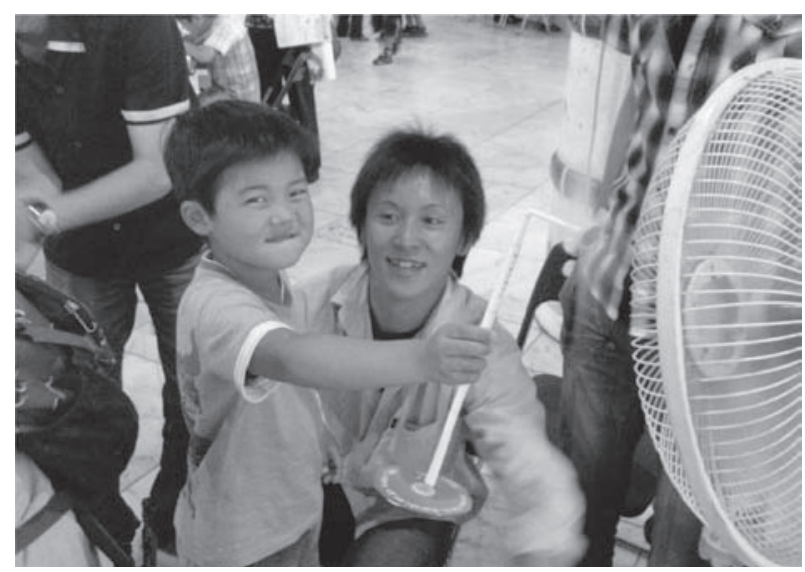

図 9 ひたち環境都市フェスタの様子

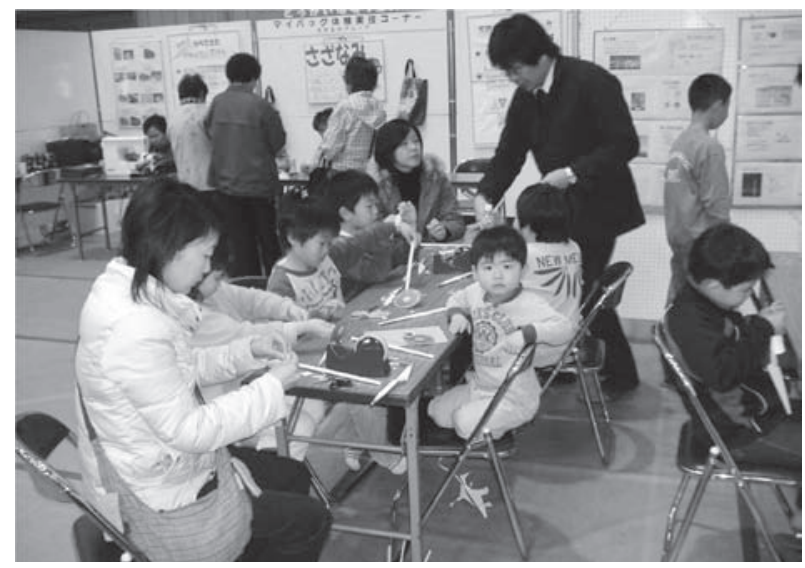

図10 とうかい環境フェス夕の様子

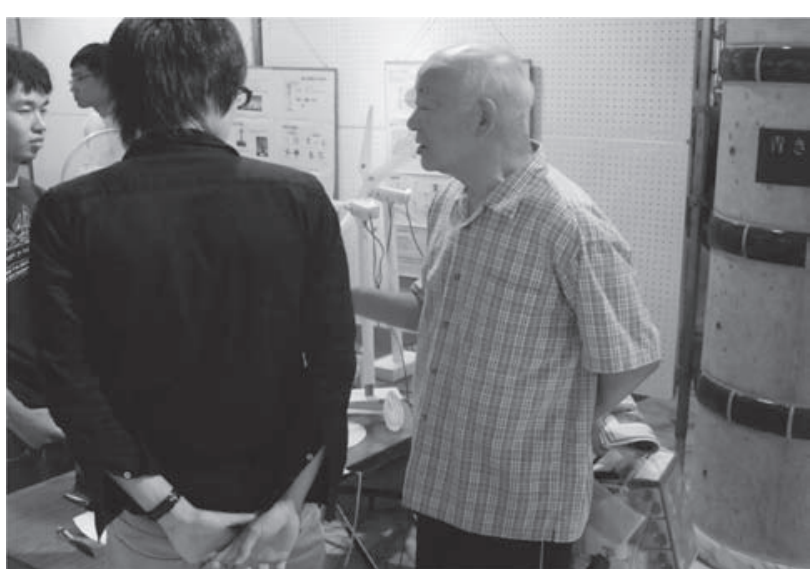

四11 対話風景

パネルやペーパークラフト製作を通じて「自然エネル ギー」,「風車」や「環境」を議論する光景も目に付い た.このような場では, 学生自らがそれらの問題に関 する理解を深めると同時に, 地域連携の重要性の認識, コミュニケーション及びプレゼンテーション能力の涵 養も実践されるものと思われる.

\section{2 ペーパークラフトの評価}

完成したペーパークラフト風車は, 団扇の微風でも 起動する特性を有しているが, 試験用に設置された扇 風機の前には完成品の性能を確認する参加者の列が長 く出来るほどの盛況振りであった. 完成品が上手く起 動した時には, 参加者の多くが喜びの表情を浮かべ, 彼等から完成後の達成感と喜びの声が聞かれた。もの づくりの面白さを大いに感じて貪えたものと思われ る.また, 毎年参加する子供たちも見受けられ, 「去 年楽しかったからまた来たよ」,「風車大好き」などの 声も聞かれた．製作中に普段見せることのない集中力 を発揮する子供の様子に驚いている保護者もいた，参 加者から最も多く寄せられた関心は, 風車の発電量 に関するもので, 自然エネルギーとしての風力エネル ギーの可能性に大きな期待を寄せているようであっ た。ちなみに，平成21年 7 月18，19日に開催されたひ たち環境都市フェスタでは, 合計100セットほどのペー パークラフト風車が消費されるほどの盛況振りを呈し ていた. 試運転時の回転と同期して点灯するLEDの 光を見て満面の笑顔を覗かせていた。 なお，現在まで に開催した一連の理科学教室では, 各報道メディアか らも高い関心が示されている（日立ケーブルテレビ $\mathrm{JWAY}^{9}{ }^{9}$, 茨城新聞 ${ }^{10)}$ など).

平成21年 7 月 18,19 日に開催されたひたち環境都市 フェス夕参加者のうち 25 名（5歳～13歳）から得ら れた体験後のアンケート結果を図 12 , 自由㦨に記載さ れていた回答結果を図13, ペーパークラフトで難しい と感じた点に関する自由記入の回答結果を眓14に示 す.これらの集計結果から, 本ペーパークラフトが楽 しみながら環境問題や風車を学ぶことの出来る教材で あるとともに，ものづくりへの興味や関心を引かせる 


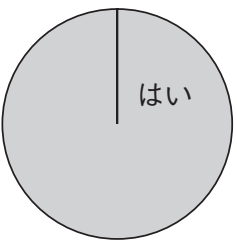

楽しかったか

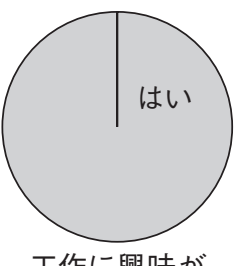

湧いたか

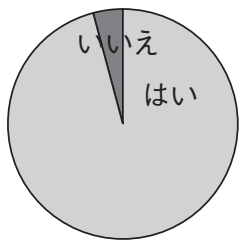

また作りたい

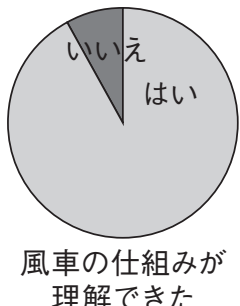

理解できた

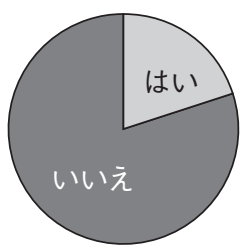

簡単だった

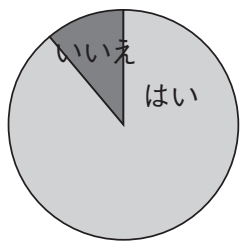

風車をさらに 知りたいと思った
図12 アンケート結果

・楽しい

・さらに大きいものを作りたい

・綺麗に完成して嬉しい

・また作りたい

・風車が回転すると嬉しい

・夏休みの宿題に活用できる

・難しい

図13アンケート結果（自由記入）

\begin{tabular}{|c|c|}
\hline ・ストローの挿入・ & (1名) \\
\hline •紙を巻く作業……………… & (2名) \\
\hline •切る作業…………………........ & (7 名) \\
\hline ·翼部分の作業· & (2名) \\
\hline •貼る作業………………….... & (4 名) \\
\hline • モーター周辺作業……….. & (1名) \\
\hline
\end{tabular}

図14 アンケート結果（難しいと感じた点 自由記入）

教材であることが明らかになった，すなわち，「風車 について理解できた」,「もっと風車について知りたい」 などの意見が寄せられた。ほぼ全ての参加者から完成 後の達成感や充実感などの感想も寄せられている。 ま た，参加者の $83 \%$ 「製作が難しい」と回答していた が,「また作りたい」，「工作に興味が湧いた」などの 回答も得られた。

以上を総合すると，翼形状の忠実なモデル化と簡便 な製作指針に基づいて新たに設計・開発したペーパー クラフト風車は, 地域の青少年向け理科学教室の開催 を通じて環境問題や理科学への興味や関心の向上を図 るだけではなく, 学部学生向け専門基礎教育としての 機械工学実験向け教材としても有効となろう。アン ケート回答者は小中学生が中心であったが，対象年齢 をより年長者まで拡大した場合，教育教材としての価 值がさらに高まることも予想される．学部学生向け専 門教育教材としての適応性評価については, 茨城大学
工学部内に設備されている大型風洞装置にペーパーク ラフト風車数台から構成される風況ジオラマを実際に 設置し, 平成 22 年 4 月から機械工学科 3 年次開講の機 械工学実験（課題名：風車の原理と模型製作）に応用 して一連の成果を分析する予定である.

\section{3 大学院生による自己評価}

平成19年, 20年, 21 年度のひたち環境都市フェスタ, とうかい環境フェスタに参加した大学院生及び風力研 究会の大学院生合計 16 名から採取した体験後の自己評 価結果（自由記入形式）を以下に簡易にまとめておく.

コミュニケーション能力の向上に繋がったと思われ る点：1）風力エネルギーを始めとする環境問題全般 に関する地域住民との議論，2）実機のモデル化に際 して派生した技術的な諸問題に関する地域住民との議 論, 3 ) 風車に関わる流体力学的な諸問題に関する地 域住民との議論，4）環境や人に優しいものづくりに 関する地域住民への提案力, などが深まり, 自身の技 術的知識と発言力の向上に役立った。一方，5）参加 者への積極的な関与と科学的・技術的なディベートの 仕方及び知識不足について改善の余地がある.

プレゼンテーション能力の向上に繋がったと思われ る点：1）技術的な知識が少ない地域住民へ如何に簡 易にペーパークラフト風車の仕組みと組立方法を伝え るか，2）環境や人に優しいものづくりとは何かを如 何に簡易に伝えるか，3）環境問題や風力発電につい ての解説パネルを如何にデザインするか，などについ て様々な工夫をした。一方，4）コミュニケーション やプレゼンテーションを通じて自己の工学的・技術的 な知見の不備に気付き, 改善の余地がある.

\section{4.まとめ}

本研究は,「地域連携を活用した学生による学生の ための技術者教育（ものづくり理科教室）」を企画 · 実践し，その評価について具体的に述べたものである. 設定した研究目的は，1）地域貢献を志向した地域に 根ざした理工学技術者の養成とコミュニケーション及

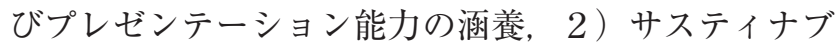
ルな環境教育の具現化による教育教材の開発，3）青 少年の理工学離れ防止, 4) 茨城大学の広報活動, で ある. ここでは, 流体力学的な考察に基づいて独自に 開発したペーパークラフト風車を活用し, 茨城大学 理工学研究科の大学院生自らが大学と地域コミュニ ティー相互の連携組織を活用しながら各目的を実現し た. 目的達成のプロセスは, 学生自らが企画し, 学生 自らが運営した「ものづくり」の実践の場ともなった. したがって,「学生による学生のための技術者教育（も のづくり「理科教室」）の実践」の目的を充分に果た せたものと考えている.

本ペーパークラフト風車は, コンパクトさ故に地域 の小中高等学校訪問などの出前授業へも今後積極的に 
活用する予定である. 茨城大学工学部内に設備されて いる大型風洞装置にペーパークラフト風車数台から構 成される風況ジオラマを実際に設置して，基礎的な機 械工学教育向け教材としても評価を加える予定であ る.

\section{参 考 文 献}

1) 文部科学省科学技術政策研究所：科学技術に関す 意識調查 -2001 年 $2 \sim 3$ 月調査 - 概要, 2001

2 ) 文部科学省科学技術政策研究所: 科学技術指標日本の科学技術の体系的分析 - , 2004

3 ) 文部科学省科学技術政策研究所: 科学技術システ 么の課題に関する代表的研究者・有識者の意識 定点調査(科学技術システム定点調査2007, 2008), 2008, 2009

4) 安高志穂ほか 4 名：インターネットを利用した科 学技術に関する意識調査の試み, 文部科学省科学 技術政策研究所, 2008

5 ) OECD : 生徒の学習到達度調査(PISA) 2000, 2003, 2006年調查国際結果報告書, 2000, 2003, 2006

6 ）国立教育政策研究所：理科の学力とそれの影響に 与える諸因子の経年変化, 国立教育政策研究所紀 要第136集, 2007
7 ）環境省：事務次官会見要旨, 2009年 6 月 25 日

8 ）稲垣照美, 立川 力, 杉森健志：地域連携を活用し た学生による学生のための継続的な技術者教育の 実践と評価, 工学教育, 58-4, pp.46-51, 2010

9 ）日立ケーブルテレビJWAY : 市民ニュース, 2006 年 7 月 14 日, 行政ニュース, 2007年 7 月 30 日〜 8 月14日, 行政ニュース, 2007年 7 月 30 日〜 8 月 4 日, 行政ニュース, 2008年 7 月14日〜 7 月19日, ま なびピアいばらき2006, 2006年10月 1 日〜 10月 7 日

10）茨城新聞：ひたちいきいき百年塾 (日立教育プラ ザ)に打ける取組, 2005年10月24日

著者 紹介

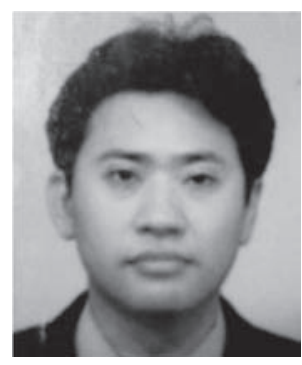

早稲田一嘉

2004年 工学博士 (茨城大学)

2008年 神戸市立工業高等専門学校准教 授 